\title{
PENGARUH KOMPETENSI KEPRIBADIAN GURU TERHADAP KECERDASAN EMOSIONAL ANAK USIA DINI DI TAMAN KANAK-KANAK ISLAM TERPADU ADZKIA III PADANG
}

\section{THE INFLUENCE OF TEACHER'S PERSONALITY COMPETENCY TO EARLY CHILDHOOD EMOTIONAL INTELLIGENCE IN KINDERGARTEN ISLAM TERPADU ADZKIA III PADANG}

\author{
Sri Wahyuni Astuti ${ }^{1}$, Serli Marlina ${ }^{2}$, Dadan Suryana ${ }^{3}$ \\ Fakultas Ilmu Pendidikan \\ Universitas Negeri Padang \\ Jl. Prof. Dr. Hamka, Air Tawar Barat, Padang \\ sriwahyuniastutut@gmail.com
}

\begin{abstract}
ABSTRAK
Tujuan dari penelitian ini adalah untuk melihat pengaruh kompetensi kepribadian guru terhadap kecerdasan emosional anak di Taman Kanak-kanak Islam Terpadu Adzkia III Padang. Jenis penelitian ini adalah penelitian kuantitatif dengan metode korelasional. Berdasarkan analisis data, diperoleh koefisien korelasi antara kompetensi kepribadian guru terhadap kecerdasan emosional anak sebesar 0.725 dan koefisien determinasinya sebesar 0.526. Hasilnya diperoleh kompetensi kepribadian guru sebesar $72.5 \%$ terhadap kecerdasan emosional anak signifikan pada taraf 5\%. Dapat disimpulkan bahwa kompetensi kepribadian guru mempunyai pengaruh yang signifikan terhadap kecerdasan emosional anak usia dini di Taman Kanak-kanak Islam Terpadu Adzkia III Padang sebesar $72.5 \%$.
\end{abstract}

Kata Kunci: kompetensi kepribadian guru, kecerdasan emosional anak

\begin{abstract}
The purpose of this research is to look at. influence of teacher's personality competency to early childhood emotional intelligence in integrated islamic kindergarted adzkia III padang. This type of research with correlational methods. Based on data analysis, a correlation coefficient was obtained between teacher's personality competence and chidren's emotional intelligence of 0,725 and a determination coefficient of 0,526. The results obtained by the teacher's personality competence were $72.5 \%$ of the significance of children's emotional intelligence at the 5\% level. It can be concluded that the teacher's personality competence has a significant influence to the emotional intelligence of early childehood in the kidergarten Islam Terpadu Adzkia III Padang at 72.5\%.
\end{abstract}

Keywords: teacher's personal competence, child emotional intelligence

\section{PENDAHULUAN}

Guru sebagai figur manusia sumber yang menempati posisi dan memegang peranan penting dalam pendidikan. Guru merupakan komponen yang paling berpengaruh terhadap proses dan hasil pendidikan yang berkualitas. Kualitas guru meliputi kedisiplinan, kreativitas, tanggung jawab, etos kerja tinggi, kemampuan mengembangkan diri, mampu mengikuti perkembangan zaman dan sebagainya.

Menurut Marlina (2017) adapun standar kompetensi guru taman kanak-kanak /PAUD meliputi 1. Kompetensi kepribadian, 2. Kompetensi professional, 3. Kompetensi 
pedagogic, 4. Kompetensi social. Guru yang professional adalah guru yang memiliki kepribadian yang baik. Pribadi guru memiliki andil yang sangat besar terhadap keberhasilan pendidikan, khususnya dalam kegiatan pembelajaran. pribadi guru juga sangat berperan dalam membentuk pribadi peserta didik

Kompetensi kepribadian guru sangat besar pengaruhnya terhadap pertumbuhan dan perkembangan pribadi peserta didik. Menurut Mulyasa (2008:117) kompetensi kepribadian ini memiliki peranan dan fungsi yang sangat penting dalam membentuk kepribadian anak, guna menyiapkan dan mengembangkan sumber daya manusia (SDM), serta mensejahterakan masyarakat, kemajuan negara, bangsa dan pada umumnya.

Sjarkawi (2006:11) Kepribadian adalah ciri atau karakteristik atau gaya atau sifat khas dari diri seseorang yang bersumber dari bentukan-bentukan yang diterima dari lingkungan, misalnya, keluarga pada masa kecil, dan juga bawaan seseorang sejak lahir.

Sigmund freud (dalam Sjarkawi 2006:17) Kepribadian merupakan struktur yang terdiri dari tiga system, yakni id, ego dan super- ego. sedangkan tingkah laku tidak lain merupakan hasil dari konflik dan rekonsiliasi ketiga unsur dalam system kepribadian tersebut. Dalam Sandar Nasional Pendidikan, penjelasan Pasal 28 ayat (3) butir b, dikemukakan bahwa yang dimaksud dengan kompetensi kepribadian adalah kemampuan pribadi yang mantap, stabil, dewasa, arif, bijaksana Setiap aspek perkembangan anak harus dikembangkan dengan optimal, salah satunya adalah perkembangan emosi anak. Pada hakikatnya, kecerdasan emosi adalah suatu jenis kecerdasan yang memusatkan perhatiannya dalam mengenali, memahami, merasakan, mengelola, memotivasi diri sendiri dan orang lain serta dapat mengaplikasikan kemampuannya tersebut dalam kehidupan pribadi dan sosialnya.

Emosi berperan dalam memengaruhi kepribadian dan penyesuaian diri anak. Berdasarkan hasil penelitian Yatimah (2014) bahwa kompetensi kepribadian guru berpengaruh terhadap kecerdasan emosional. Menurut Susanto (2011:157) Kepribadian orang terdekat anak seperti guru dan orang tua akan mempengaruhi perkembangan baik social maupun emosional anak.

Menurut Santrock (2007:6) emosi adalah perasaan atau afeksi yang timbul ketika seseorang sedang berada dalam suatu keadaan atau suatu interaksi yang dianggap penting olehnya. Emosi diwakili oleh perilaku yang mewakili (mengekspresikan) kenyamanan atau ketidaknyamanan dari keadaan atau interaksi yang sedang dialaminya. Emosi juga bisa berbentuk spesifik seperti rasa senang, takut, marah, dan seterusnya tergantung dari interaksi yang dialami. Dalam perkembangan emosi, proses modeling terhadap lingkungan mikro dapat terbentuk ketika anak mendapat stimulasi berupa pengalaman-pengalaman emosi dari 
orang-orang yang ada disekitarnya. Kecerdasan emosi perlu diasah sejak dini, karena kecerdasan emosi merupakan salah satu poros keberhasilan individu dalam berbagai aspek kehidupan. Kemampuan anak mengembangkan kecerdasan emosinya, berkorelasi positif dengan keberhasilan akademis, social dan kesehatan anak. Anak yang memiliki kecerdasan emosi tinggi identik dengan anak yang bahagia, bermotivasi tinggi dan mampu bertahan dalam menjalani betbagai kondisi stress yang dihadapi orang tua dan pendidik memiliki peranan penting dalam menstimulasi kecerdasan emosi anak .

Goleman (dalam Suyadi 2014:120) kecerdasan emosional sebagai kemampuan untuk memotivasi diri dan bertahan menghadapi frustasi, mengendalikan dorongan hati, dan tidak melebih-lebihkan kesenangan, mengatur suasana hati dan menjaga agar beban stres tidak melumpukan kemampuan berpikir,berempati, dan berdoa. Mashar ( 2011:60) Kecerdasan emosi adalah kemampuan untuk mengenali, mengontrol emosi agar anak mampu merespon secara positif setiap kondisi yang merangsang munculnya emosi-emosi ini.

Steven J. Stein dan Howard E. Book (dalam Uno 2006:69) kecerdasan emosi adalah kemampuan untuk mengenali perasaan, meraih dan membangkitkan perasaan untuk membantu pikiran, memahami perasaan dan maknanya, mengendalikan perasaan secara mendalam sehingga membantu perkembangan emosi dan intelektual.

Guru yang profesional dalam tugasnnya akan mampu mengajarkan pada anak bagaimana agar anak memiliki kemampuan untuk mengenal, menerima, dan berbicara tentantang perasaannya, melatih anak agar mampu mengungkapkan emosinya dengan baik serta mampu mengajarkan kepada anak untuk peka terhadap perasaan dan kebutuhan orang lain. Selain itu, guru juga harus piawai dalam membantu memupuk emosi anak untuk memiliki perasaan senang dan bergairah dalam belajar, membantu memberikan dukungan rasa aman dan nyaman. Berdasarkan uraian masalah yang telah diuraikan di atas, maka masalah dalam penelitian ini dapat dirumuskan seperti: "Seberapa besar Pengaruh Kompetensi kepribadian guru terhadap kecerdasan Emosional anak di Taman kanak-kanak IslamTerpadu Adzkia III Padang?’Dan tujuan dalam penelitian ini adalah untuk mengetahui seberapa besar Pengaruh kompetensi kepribadian guru terhadap kecerdasan Emosional anak di Taman kanak-kanak IslamTerpadu Adzkia III Padang.

\section{METODE PENELITIAN}

Metode yang digunakan dalam Jenis penelitian ini adalah penelitian kuantitatif korelasional. Populasi dalam penelitian ini adalah seluruh guru yang mengajar di Taman Kanak-kanak Islam Terpadu Adzkia III Padang dan anak usia 5-6 tahun di kelas masjidil 
aqsha 6 dan 7 . sampel pada penelitian ini adalah total sampling karena pengambilan datanya secara keseluruhan dari populasi tersebut yaitu sebanyak 29 orang guru dan cluster sampling untuk pengambilan sampel pada anak yang berusia 5-6 tahun pada kelas masjidil aqsha 6 dan 7. Instrumen ini menggunakan skala likert, butir pernyataan untuk tingkat pemahaman model skala likertnya yaitu: Selalu (SL) diberi bobot 5, Sering (SR) diberi bobot 4, Kadang-kadang (KD) diberi skor 3, Jarang (JR) diberi skor 2, dan Tidak Pernah (TP) diberi skor 1.

Penelitian ini dilakukan dengan menyebarkan angket kepada seluruh responden yang telah ditetapkan yaitu seluruh guru yang mengajar di Taman Kanak-kanak Islam Terpadu Adzkia III Padang. Sebelum menyebarkan angket kepada responden di tempat penelitian terlebih dahulu peneliti melakukan uji coba instrument. di tempat validasi yaitu di Gugus Bougenville I padang sebanyak 26 orang guru. Uji ini dilakukan untuk mengetahui apakah instrumen yang disusun valid, artinya instrumen itu dapat mengukur apa yang seharusnya diukur .

Uji reliabilitas bertujuan untuk mengetahui apakah keadaan instrumen yang digunakan memiliki ketetapan yang sama dalam mengukur, artinya instrumen yang bisa digunakan beberapa kali untuk mengukur obyek yang sama akan menghasilkan data yang sama. Teknik pengujian reliabilitas yang digunakan dalam penelitian ini menggunakan formula alpha dari crombach dengan bantuan program SPSS versi 16.

Uji normalitas dilakukan untuk mengetahui normal tidaknya suatu distribusi data (Muhidin dan Sambas, 2011:73). menyatakan: "uji normalitas digunakan untuk mengetahui apakah data yang akan diolah berasal dari data berdistribusi normal. Uji normalitas dilakukan sebelum mengolah data dengan teknik korelasi product moment, regresi, $t$-test, anava dan sebagainya." Untuk uji normalitas ini digunakan rumus Kolmogrov Smirnov dengan bantuan SPSS versi 16.

Pengujian linearitas bertujuan untuk mengetahui pengaruh antara variabel $\mathrm{X}$ dengan variabel Y linear atau tidak. Untuk itu digunakan uji F. Uji linearitas dilakukan dengan bantuan Program Analisis Statistik Pendidikan SPSS versi 16. Pengaruh antara variable X dengan Variabel $\mathrm{Y}$ dikatakan linear apabila $\mathrm{F}_{\text {hitung }}>\mathrm{F}_{\text {tabel. }}$

Hipotesis pada penelitian ini adalah hipotesis asosiatif. Sugiyono (2012:254) mengatakan bahwa hipotesis asosiatif merupakan dugaan terhadap ada tidaknya hubungan secara signifikan antara dua variabel atau lebih. Pengujian hipotesis digunakan untuk melihat pengaruh Kompetensi Kepribadian Guru (X) dengan Kecerdasan Emosional Anak (Y) digunakan rumus koefisien korelasi Product dengan bantuan program SPSS versi 16. 


\section{HASIL PENELITIAN}

Data penelitian ini terdiri dari dua variabel yaitu kompetensi kepribadian guru $(\mathrm{X})$ dan kecerdasan emosional anak (Y). deskripsi data ini mengungkapkan informasi tentang ratarata, skor tengah,skor yang paling banyak muncul, simpangan baku, keragaman, rentangan, skor terendah, skor tertinggi dan jumlah skor. Distribusi data tentang kompetensi kepribadian guru dan kecerdasan emosional anak dengan menggunakan bantuan program SPSS versi 16. Data yang diperoleh dari kompetensi kepribadian guru dengan kecerdasan emosional anak dapat dilihat pada tabel berikut ini :

Deskriptif data penelitian

Statistics

\begin{tabular}{|l|r|r|}
\hline & $\begin{array}{c}\text { kompetensi } \\
\text { kepribadian } \\
\text { guru }\end{array}$ & $\begin{array}{c}\text { kecerdasan } \\
\text { emosional } \\
\text { anak }\end{array}$ \\
\hline Nalid $\quad$ Missing & 29 & 29 \\
Mean & 0 & 0 \\
Median & 62.28 & 57.72 \\
Mode & 65.00 & 57.00 \\
Std. Deviation & 53 & 57 \\
Variance & 12.323 & 10.416 \\
Minimum & 151.850 & 108.493 \\
Maximum & 31 & 27 \\
Sum & 83 & 80 \\
\hline
\end{tabular}

Data kompetensi kepribadian guru (X) dikumpulkan melalui angket yang terdiri dari 18 butir pernyataan yang telah diuji validasi dan reabilitasnya. Selanjutnya angket disebarkan kepada 29 orang guru sebagai responden untuk diisi. Dari data penelitian diketahui distribusi skor jawaban menyebar dari skor terendah 31 berada pada responden nomor 23 dan skor tertinggi 83 berada pada responden nomor 19 . Dari data distribusi skor tersebut didapat ratarata (mean) sebesar 62.28, skor tengah (median) 65.00 ,skor yang sering muncul (mode) 53 dan simpangan baku (standar deviasi) 12.323.

Data kecerdasan emosional anak (Y) dikumpulkan melalui angket yang terdiri dari 16 butir pernyataan yang telah diuji validitas dan reabilitasnya. Selanjutnya angket disebarkan kepada guru untuk diisi. Dari data penelitian diketahui bahwa distribusi skor jawaban menyebar dari skor terendah 27 berada pada responden nomor 23 dan tertinggi 80 berada 
pada responden nomor 19. dari data distribusi tersebut didapat rata-rata (mean) sebesar 57.72, skor tengah (median) 57.00 , skor yang sering muncul (mode) 57 dan simpangan baku (standar deviasi) 10.416.

Pada analisis data menerangkan bahwa nilai signifikasi probalitas variabel $\mathrm{X}$ sebesar 0.604 dan variabel Y sebesar $\mathbf{0 . 5 7 9}$ yang lebih besar dari signifikasi $\alpha 0,05$. Berdasarkan landasan pengambilan keputusan di atas, $\mathbf{H}_{\mathbf{a}}$ diterima dan $\mathrm{H}_{0}$ ditolak, dengan demikian dapat diambil kesimpulan bahwa data kedua variabel dalam penelitian ini memiliki distribusi normal

Rangkuman uji normalitas variabel $X$ dan $Y$

One-Sample Kolmogorov-Smirnov Test

\begin{tabular}{|c|c|c|c|}
\hline & & $\begin{array}{c}\text { kompetensi } \\
\text { kepribadian guru }\end{array}$ & $\begin{array}{c}\text { kecerdasan } \\
\text { emosional anak }\end{array}$ \\
\hline \multicolumn{2}{|l|}{$\mathrm{N}$} & 29 & 29 \\
\hline Normal & Mean & 62.28 & 57.72 \\
\hline Parameters $^{\mathrm{a}}$ & Std. Deviation & 12.323 & 10.416 \\
\hline Most Extreme & Absolute & .142 & .145 \\
\hline \multirow[t]{2}{*}{ Differences } & Positive & .066 & .145 \\
\hline & Negative & -.142 & -.119 \\
\hline \multicolumn{2}{|c|}{ Kolmogorov-Smirnov Z } & .764 & .779 \\
\hline \multicolumn{2}{|c|}{ Asymp. Sig. (2-tailed) } & .604 & .579 \\
\hline \multicolumn{2}{|c|}{ a. Test distribution is Normal. } & & \\
\hline
\end{tabular}

Berdasarkan pengujian yang dilakukan diperoleh $F_{\text {hitung }}=\mathbf{2 9 , 9 9 9 6}>F_{\text {tabel }}=4,24$ angka $\mathrm{F}_{\text {tabel }}$ diperoleh dari 1.27 dan melihatnya pada tabel distribusi F0.05 degress of freedom for nominar, maka diperoleh $\mathrm{F}_{\text {tabel }}=4,24$. Maka dapat disimpulkan bahwa antara kompetensi kepribadian guru terhadap kecerdasan emosional anak memiliki hubungan yang linear .

\section{Uji F}

\begin{tabular}{|l|r|r|r|r|r|}
\hline \multicolumn{1}{|l|}{ Model } & Sum of Squares & Df & Mean Square & F & Sig. \\
\hline $1 \quad$ Regression & 1598.744 & 1 & 1598.744 & 29.996 & $.000^{\mathrm{a}}$ \\
Residual & 1439.049 & 27 & 53.298 & & \\
\multicolumn{1}{|l|}{ Total } & 3037.793 & 28 & & & \\
\hline
\end{tabular}

a. Predictors: (Constant), kompetensi kepribadian guru 


\begin{tabular}{|l|r|r|r|r|r|}
\hline \multicolumn{1}{|l|}{ Model } & Sum of Squares & Df & Mean Square & F & Sig. \\
\hline $1 \quad$ Regression & 1598.744 & 1 & 1598.744 & 29.996 & $.000^{\mathrm{a}}$ \\
Residual & 1439.049 & 27 & 53.298 & & \\
\multicolumn{1}{|c|}{ Total } & 3037.793 & 28 & & & \\
\hline
\end{tabular}

b. Dependent Variable: kecerdasan emosional anak

Hipotesis yang diajukan adalah "terdapatnya pengaruh kompetensi kepribadian guru dengan kecerdasan emosional anak di Taman Kanak-Kanak Islam Terpadu Adzkia III Padang”. Dari hasil perhitungan diperoleh koefisien korelasi X terhadap Y sebesar 0,725 Hasil perhitungan pada tabel 13 di atas menunjukkan bahwa besarnya determinasi kompetensi kepribadian guru terhadap kecerdasan emosional anak sebesar 0,725 .

koefisien korelasi antara kompetensi kepribadian guru terhadap kecerdasan emosional pada anak di taman Kanak-kanak Islam Terpadu Adzkia III Padang sebesar 0,725 . dengan $(\operatorname{sig})=0,00<\alpha=0,05$ Ini berarti bahwa terdapat pengaruh yang kuat antara kompetensi kepribadian guru dengan kecerdasan emosional anak di taman Kanak-kanak Islam Terpadu Adzkia III Padang sebesar 0.725 atau 72,5\% Berdasarkan perhitungan di atas diketahui harga $t_{\text {hitung }}$ sebesar 0,725 untuk $\alpha$ 0,05 dan df 29 didapat $t_{\text {tabel }}$ 0367. Kemudian $t_{\text {hitung }}$ yang diperoleh dikonsultasikan dengan $t_{\text {tabel}}$, terlihat $t_{\text {hitung }}>t_{\text {tabel. }}$. Hal ini menunjukkan adanya pengaruh positif dan berarti antara kompetensi kepribadian guru dengan kecerdasan emosional anak. Sehingga hipotesis pada penelitian ini "terdapat kontribusi yang positif dan berarti antara kompetensi kepribadian guru dengan kecerdasan emosional anak". Akan tetapi dengan melihat kontribusi yang diberikan kompetensi kepribadian guru dengan kecerdasan emosional anak di taman Kanak-kanak Islam Terpadu Adzkia III Padang sebesar 72,5\%, maka dapat dikatakan bahwa terdapat hubungan yang kuat antara kompetensi kepribadian guru dengan kecerdasan emosional anak di Taman Kanak-kanak Islam Terpadu Adzkia III Padang.

\section{PEMBAHASAN}

Berdasarkan hasil penelitian di Taman Kanak-kanak Islam Terpadu Adzkia III Padang ditemukan bahwa terdapat pengaruh kompetensi kepribadian guru terhadap kecerdasan emosional anak. Hal ini terbukti bahwa kompetensi kepribadian guru sesuai dengan aspek memahami perbedaan anak, memiliki rasa empati serta mampu memberikan dorongan kepada anak dan memahami dampak dari kompetensi kepribadian terhadap aspek kecerdasan 
emosional anak. Kecerdasan emosional anak dapat dilihat dari bagaimana anak mampu memahami emosi diri sendiri dan mampu mengendalikan emosi diri sendiri, anak mampu memahami emosi orang lain, anak dapat berinteraksi social dan membina hubungan baik dengan orang lain dan lingkungannya.

Hasil penelitian di Taman Kanak-kanak Islam Terpadu Adzkia III Padang diperoleh nilai korelasi antara kompetensi kepribadian guru terhadap kecerdasan emosional anak sebesar, 0,725 dan koefisien determinasinya sebesar 0,367. Hal ini berarti bahwa kompetensi kepribadian guru sebesar 72,5\% terhadap kecerdasan emosional anak di Taman Kanak-kanak Islam Terpadu Adzkia III Padang kuat pada taraf 5\%. Dapat dikatakan bahwa kompetensi kepribadian guru mempunyai hubungan yang kuat terhadap kecerdasan emosional anak di Taman Kanak-kanak Islam Terpadu Adzkia III Padang sebesar 72,5\% Dari hasil analisis diatas dinyatakan bahwa jika tidak dilakukan pengontrolan terhadap faktor lain, maka kompetensi kepribadian guru untuk kecerdasan emosional pada anak sebesar 72,5\% selebihnya 27,5 lagi disebabkan oleh faktor lain.

Menurut Susanto (2011:157) Kepribadian orang terdekat anak seperti guru dan orang tua akan mempengaruhi perkembangan baik social maupun emosional anak. Berdasarkan hasil penelitian Yatimah (2014) bahwa kompetensi kepribadian guru berpengaruh terhadap kecerdasan emosional hal ini terbukti dengan adanya perubahan emosional positif dalam diri siswa yang dapat dilihat dari hasil prestasi, etika pergaulan, budipekerti, motivasi dan kemampuan mereka bersosialisasi dengan baik dalam kehidupan sehari-hari. Emosi berperan dalam memengaruhi kepribadian dan penyesuaian diri anak. Untuk meningkatkan kecerdasan emosi anak, pendidik perlu memberikan rangsangan-rangsangan yang sesuai, sehingga anak dapat mempelajari keterampilan-keterampilan emosi dan sosial yang baru.

Mulyadi (2004:10) anak adalah seorang pemain amatir dalam hal emosi. Pada awal perkembangannya, anak pasti mengalami kesulitan untuk memahami dan mengelola emosi, baik emosi yang dirasakan maupun emosi orang lain. Anak harus terlebih dahulu mampu memahami dan mengelola emosinya sendiri sebelum mampu menjadi individu yang memahami emosi orang lain.

Berdasarkan hasil penelitian tersebut kompetensi kepribadian guru memiliki pengaruh dengan kecerdasan emosional anak. Apabila guru menstimulasi kecerdasan emosional anak sesuai dengan tahapan yang seharusnya, maka kecerdasan emosional anak akan terstimulasi dengan baik. Namun apabila guru memiliki kepribadian yang kurang baik maka akan cendrung memberikan dampak negative terhadap kecerdasan emosional anak. Sehingga 
penelitian ini dapat membuktikan bahwa kompetensi kepribadian guru memiliki hubungan dengan kecerdasan emosional anak.

\section{SIMPULAN}

Berdasarkan hasil penelitian dan pembahasan pada bab sebelumnya bahwa terhadap hubungan kompetensi kepribadian guru terhadap kecerdasan emosional anak ditaman kanak-kanak Islam Terpadu Adzkia III Padang dengan sig> 0,05 dan sumbangan yang diberikan oleh kompetensi kepribadian guru 0,725 artinya bahwa kompetensi kepribadian guru memiliki pengaruh yang kuat terhadap kecerdasan emosional anak. Dapat disimpulkan bahwa kompetensi kepribadian guru memiliki pengaruh terhadap kecerdasan emosional anak. Apabila guru memiliki kepribadian yang sesuai dengan tahapan perkembangan emosional anak maka emosional anak akan terstimulasi dengan baik dalam kehidupan sehari-hari dan apabila guru memiliki kepribadian yang tidak sesuai dengan tahapan perkembangan emosional anak maka kecerdasan emosional tidak akan terstimulasi dengan baik.

\section{SARAN}

Berdasarkan penelitian di atas dapat diberikan beberapa saran sebagai berikut: 1). Diharapkan kepada guru agar memiliki kompetensi kepribadian yang baik dan sesuai dengan perkembangan emosional anak. 2). Bagi peneliti, hasil penelitian ini semoga dapat diaplikasikan pada saat mengajar di taman kanak-kanak Islam Terpadu Adzkia III Padang dan dapat dikembangkan lebih baik. 3). Bagi peneliti selanjutnya, hasil penelitian ini dapat menjadi sumber bacaan/literatur selanjtnya bagi peneliti lain untuk mengembangkan penelitian yang sama.

\section{DAFTAR PUSTAKA}

Marlina, Serli dan Indra Jaya. 2017. Hubungan kualifikasi akademik guru dengan kompetensi pedagogic guru di TK Kartika Padang. Padang: Jurusan Administasi Pendidikan FIP UNP

Mashar, Riana. 2011. Emosi Anak Usia Dini Dan Strategi Pengembangannya. Jakarta: Kencana

Mulyadi, Seto.2004. Membantu Anak Balita Mengelola AmarahnyaI. Jakarta:Erlangga

Mulyasa, .2008. Standar Kompetensi dan Sertifikasi Guru. Bandung: Remaja Rosdakarya Offset. 
Sjarkawi, 2006 .Pembentukan Kepribadian Anak ( Peran Moral Intelektual, Emosional, Dan Social Sebagai Wujud integritas Membangun Jati Diri). Jakarta:PT Bumi Aksara

Sugiyono. 2012. Statistika untuk penelitian. Bandung: Alfabeta.

Susanto,Ahmad. 2011. Perkembangan Anak Usia Dini ( Pengantar Dalam Berbagai Aspek). Jakarta: Kencana Prenada Media Group

Suyadi. 2010. Psikologi Belajar Pendidikan Anak Usia Dini. Yogyakarta: PT Bintang Pustaka Abadi

Uno, Hamzah. 2006. Orientasi Baru Dalam Psikologi Pendidikan. Jakarta :PT Bumi Aksara

Yatimah. 2014 Kompetensi Kepribadian Guru PAI dalam mengembangkan kecerdasan emosional siswa Kelas II SD Negeri 1 Cepedak Bruno Purworejo Tahun 2013/2014 diakses tanggal 06 juni 2018

\section{PERSANTUNAN}

Artikel ini diolah dari skripsi Sri Wahyuni Astuti dengan judul "Pengaruh Kompetensi Kepribadian Guru Terhadap Kecerdasan Emosional Anak Usia Dini di Taman Kanak-kanak Islam Terpadu Adzkia III Padang”. Terima kasih kepada dosen pembimbing I Ibu Serli Marlina,M.Pd dan pembimbing II Bapak Dr. Dadan Suryana atas dukungan, bimbingan dan kesabarannya. Terima kasih atas ilmu dan waktu yang telah ibu dan bapak berikan, karena nasehat ibu dan bapak artikel ini menjadi lebih baik 